\title{
POLANYI'S ECONOMIC EMBEDDEDNESS, COUNTERMOVEMENT, AND REPUBLICAN POLITICAL ECONOMY
}

\author{
A INCRUSTAÇÃO ECONÓMICA, O DUPLO MOVIMENTO E A \\ ECONOMIA POLÍTICA REPUBLICANA EM POLANYI
}

Bru Lain*

bru.lain@ub.edu

\begin{abstract}
The aim of this article is to contend that Karl Polanyi's work bears significant coincidences with the republican tradition of thought. The first of them is one of a methodological or epistemological kind, and it consists of the use of a very similar "social ontology". The second one is of a substantive sort, and it is related to the "material conditions for freedom" which derive from a very similar conception of freedom and property. In the third section, we propose a republican reading of Polanyi's work based on three of the author's primary notions, those of "economic embeddedness", "double movement", and "political economy". The article concludes by arguing that such concepts may prove useful both for understanding the democratic-republican program and for underlining its present validity in contemporary market societies.
\end{abstract}

Keywords: Polanyi, Republicanism, Property, Freedom, Material Independence, Political Economy.

Sumário. O objetivo deste artigo é defender que a obra de Karl Polanyi guarda importantes coincidências com o pensamento republicano. A primeira, de tipo metodológico ou epistemológico, é o uso de uma "ontologia social" muito similar. A segunda, de tipo substantivo, gira em torno da ideia das "condições materiais da liberdade" baseada numa concepção muito parecida da liberdade e da propriedade. A terceira seção sugere a leitura republicana da obra de Polanyi baseada em três de suas ideias fundamentais: a "incrustação económica", o "duplo movimento" e a "economia política". O artigo conclui defendendo que tais conceitos podem ser úteis tanto para compreender o programa republicano-democrático como para sublinhar sua vigência nas sociedades de mercado contemporâneas.

Palavras-chave: Polanyi, republicanismo, propriedade, liberdade, independência material, economia política.

* Associated professor of Sociology at the University of Barcelona and of Economy at Elisava University. 


\section{o. Introduction: Karl Polanyi's Possible Republican Alignment}

Hungarian historian, sociologist, economist and anthropologist Karl Polanyi (1886-1964) has been alternatively described as a "left-wing liberal", a "democratic socialist", a "functional socialist" or a "Christian humanist" (Baum, 1996; Block, 2003; Burawoy, 2003; Dale, 2016; Laín, 2014; Mendell, 2003). However, his possible links to the republican tradition of thought have never been duly acknowledged. Because of such lack of consensus among scholars, we feel compelled to defend the hypothesis that his work is significantly connected to the republican political-philosophical tradition and, in particular, to the more democratic version of it.

Since the first third of the twentieth century republicanism "has been the object of renewed interest, first and most decidedly among historians, and then, in a more restricted manner, among law students, philosophers and political scientists" (Goodin, 2003: 55). As it has been pointed out by several authors, "there is no doubt that a re-emergence of republicanism is under way" (Dagger, 2006: 151). ${ }^{1}$ Beyond the academic realm, we should also take into account a broad group of classical and modern thinkers, from Aristotle and Cicero, to Machiavelli, Rousseau, Locke, Kant or Smith, among others. Additionally, we should also take heed of the contributions of such activists as Overton and Libourne, as well as Paine, Jefferson and Robespierre, to name only a few. There are significant differences among the authors commonly associated with this tradition in both the academic domain and the political one. However, in its more than 2,500 years of existence, republican thought has always exhibited a certain set of shared methodological and ontological principles that enable us to speak of the existence of a "social ontology" of a republican kind. Our question here is: to what degree does Polanyi's work share this social ontology?

\footnotetext{
Some of the contributors to the re-emergence of republicanism is the so-called Cambridge School, headed by J. G. A. Pocock (1975) and Quentin Skinner (1998, 2008), who were the target of devastating criticism by historian Ellen Meiksins Wood (2008). Philip Pettit (1997) was also a major contributor, while authors such as William H. Simon (1991); Stephen Holmes \& Cass R. Sunstein (1999); Sunstein (2004), or Bruce Ackerman (1993) flared up the debate in legal theory and constitutionalism. More recently, the interest in republicanism has also reached the areas of public policies, institutional design, theories of justice or productive democracy, e.g., with the works of Stuart White (2011); Richard Dagger (2006), or Alex Gourevitch (2013). In Spanish, the following authors stand out: Antoni Domènech (2000, 2004a, 2005); Jordi Mundó (2005, 2015); María Julia Bertomeu (2004, 2005); Daniel Raventós (2007), and David Casassas (2005, 2011).
} 


\section{Methodological Coincidences: A Shared Social Ontology}

There are several coincidences between Polanyi's work and the republican tradition, at least concerning their general worldview, i.e., their use of a very similar "social ontology" (Casassas, 2013). Both for Polanyi and for the republican tradition, social analysis starts from a set of epistemological and methodological assumptions that could be summarized as follows:

a) Polanyi and the republican tradition coincide in their recognition of the plurimotivational quality of human cognition, and in the implications that this has for the political life and the economic one. ${ }^{2}$ Polanyi contributed to the undermining of the "atomist" notion of cognition which marks the theory of rational choice and which sees human cognition as operating on a unimotivational pattern-the maximizing of choice. This critique is particularly present in Our Obsolete Market Mentality (1947), where he argues that "economic motives never formed with him the sole incentive to work", although it was "exhorted by economists and utilitarian moralists alike to discount in business all other motives than material ones." Actually, man "was still found to be acting on remarkably mixed motives, not excluding those of duty towards himself and others" (Polanyi, 1957: 115). This plurimotivational structure of human cognition has significant effects, not only on the conceptualization of the relations between individuals and markets, but also on the determination of how subjects relate to the cognitive and anthropological patterns under which social institutions -families, communities, markets, states- operate. 3

b) Both Polanyi and republicanism display a similar interest in the issue of the distribution of social output, understood as the result of more or less conflicting interactions between different social strata and classes. Certainly, the achievement of a fair or equitable distribution of social wealth was never

\footnotetext{
2 To confirm his opinion in this respect, see Polanyi, The Great Transformation ([1944] 2001, I, XVIII; GT onwards), where he refers to "economic determinism" as a false axiom used to justify the belief in individuals' "motivational monism" and aimed at providing the necessary base for the defense of putatively "self-regulated markets" and the liberal vision of them.

${ }^{3}$ In fact, Asad Zaman (2016: 47) states, “An individual's behaviour and motivations cannot be understood outside of his community and his social and historical milieu."
} 
a republican goal. On the contrary, its concerns always revolved around the protection of freedom understood as the absence of relations of domination. For republicanism, a more or less equitable distribution of social output is rather a direct economic consequence of a broader or narrower extension of freedom. In other words, for republican thinkers, the fair distribution of social wealth has a strong instrumental component; it does not constitute an end in itself and, simultaneously, it depends on the ideological option which is adopted with respect to the degree of extension that is should to the political domain of freedom. As we shall see, this is the reason why republicanism can be historically divided into a more aristocratic trend and a more democratic one.

c) Both Polanyi's work and the republican line of thought also share a common perspective in their understanding the problems of output distribution in societies, which they tackle from the standpoint of the role that historically contingent institutional structures and, particularly, class relations have played in them. As Polanyi pointed out, from an economic point of view, while "free competition leads to monopoly, freedom in property rights leads to the exploitation of the masses" (Polanyi, 1931: 1). So that, according to him and to republican thought, the distributive pattern of a particular society depends to large extent on its social class structure, on these classes' particular and conflictive interests, and on the different equilibrium of their bargain power. 4

d) Closely related to the previous point, they also coincide in the fact that they always bear in mind that the social life is actually traversed, and constituted, by multiple asymmetrical power relations, basically between the poor and the wealthy. For this reason, Polanyi argues that we must always start from the realization that "a human society from which power and coercion are absent

\footnotetext{
4 It is true, as Fred Block suggests, that "in the writing of the GT, there are few explicit references to this [class] perspective. Terms such as 'productive forces' and 'ruling classes' are completely absent” (Block, 2003: 280). However, "adopting a position vis-a-vis the middle class analogous to that of Gramsci's toward the working class", Gareth Dale suggests, "Polanyi made a case for its hegemonic role in a broad democratic bloc, to ensure leadership of the intellectual forces on a democratic foundation" (Dale, 2016: 51-2). In doing so, he reframed the classical republican goal, that is: the dissolution of all social classes -and their divergent interests- in a community of free and equal citizens, since according to Aristotle, citizens "in most cases of republican government (...) tend to be on an equal level in their nature and to have no difference at all" (Pol. I, 1259b).
} 
is not possible" (Polanyi, 1947: 116). Thus, both the bulk of the republican thought and Polanyi's own ideas are marked by a constant concern for the development and the adaptation of institutional arrangements whose design is properly grounded in such reality. 5

These four analytical-methodological guidelines, which are characteristic of republicanism, are also very present in the writings of the Hungarian thinker. ${ }^{6}$ However, we shall not linger on them here, since our purpose was nothing more than briefly pointing out their similar methodologies and the use of a very similar "social ontology". Now, our real interest in this writing is in the coincidences of a more substantive kind between Polanyi's work and the republican tradition.

\section{Substantive Coincidences: The Material Conditions for Freedom}

The first substantive coincidence that can be noted is the use of a similar definition of freedom as a starting point. According to the classical republican notion, freedom emerges when no arbitrary interferences, that is, when no domination relationships, can be observed between private individuals, or between them and public institutions.7 Eric MacGilvray (2011: 28) describes it as follows:

One is free if one is able to act under one's own initiative instead of merely reacting to the deeds of others, benevolent though they might be (...) To depend on another person, whether tyrant or patron, master or benefactor, is to be unfree (...) the free man must be economically independent, so that he does not rely on others for his (...) the secure ownership of property (...) is essential to the enjoyment of freedom.

Hence, freedom will be present as long as there are no relationships of dependence or domination between individuals, so that these are able to "act under one's own initiative." For this to happen, an individual must be materially independent-he must own property-, as absence of such property will make him inevitably dependent on the arbitrary decisions of others, "benevolent

\footnotetext{
5 As he defended, this kind of conflict "seemed inherent in economy, whether as competition of individuals or as struggle of classes (...) in present, or perhaps future, society” (GT: 89).

${ }^{6}$ For a more detailed exposition of these four points, see Domènech \& Bertomeu (2005).

${ }^{7}$ As Philip Pettit (1997: 52) points out, "one agent dominates another if and only if they have a certain power over that other, in particular a power of interference on an arbitrary basis."
} 
though they might be." 8 We should also take notice that, so that we can speak of freedom in society, two conditions must be present: "no citizen should be rich enough to be able to buy another", and no other citizen should be "so poor that he has to sell himself" (Rousseau, 1999, II, XI). This is why, "if a republican state is committed to advancing the cause of freedom as non-domination among its citizens, then it must embrace a policy of promoting socioeconomic independence" (Pettit, 1997: 158-9).

To fulfil both conditions, a Republic has to acquire an institutional order, which allows for the weaving of a social fabric free of domination relationships. Thus, it is a normative requirement of freedom the establishment of a politicaleconomic order designed to function as a safeguard that mitigates the sort of power asymmetries leading to both dependency and relationships of domination. To do so, property is a necessary condition; those who own some - and enjoy independence - will not be forced to subject themselves to the will of third parties. This is why Arthur Lee held, in 1775, that property is "the guardian of every other right,9" and Carol Rose (1996) asks herself whether property is "the keystone right." Several writers refer to this thesis - the idea of property as freedom - as the "material conditions for freedom" (Raventós, 2007; Casassas \& Raventós, 2007, Bertomeu, 2005), a notion deeply rooted in the classical republican legal order. The Roman legal category that identifies such condition of the material independent citizen is that of sui iuris (or material, and thus legally, autonomous person endowed with his own rights), in contrast with the alieni iuris (or person lacking all material, and hence, legal autonomy). It is not surprising then that, for Aristotle, and also for Marx, a misthotés or wage

\footnotetext{
8 Property should be understood here "as durable control over a set of material resources or assets that leverages one's freedom in economic exchanges by effectively securing a form of bargaining power vis-à-vis other agents. In other words, property allows one the freedom to choose who to contract with and under what conditions. In extreme cases, it offers an exit option from those exchanges that are deemed alienating, exploitative or otherwise detrimental to one's freedom, ideally by opening the door to more congenial ones" (Casassas \& De Wispelaere, 2016: 287). In sum, "property" is used here as synonym of "material independence", since this property gives individuals "a significant degree of material independence" (White, 2011: 567). Nevertheless, there might be plenty of modes of securing such material independence, even within the republican framework. On of them is by promoting the so-called Universal Basic Income (Casassas, 2007; Raventós, 2007), others might be the schemes of Property-Owning Democracy famously stated by James Meade in 1964 (Meade, 1964; Rawls 2001; O’Neill \& Williamson, 2012).
}

9 Arthur Lee, quoted in Ely (1992: 26). 
labourer, being materially dependent on another person-his employer, who is the owner of the means of production - is little more than a "part-time slave. ${ }^{10 "}$

We have just pointed out Polanyi's agreement with the thesis of the existence of "material conditions for freedom". However, in order to demonstrate such coincidence, now we must move on to explore in more depth the Polanyian links to republican idea of freedom and its relation to property.

\subsection{Freedom as Non-Domination, and Institutional Designs}

It is commonly understood that "the freedom of one person stops where that of another person begins." The logical, formal consequence of this would be that "the more limited the freedom of others is, the broader mine is". The result - one definitely lacking any substantive meaning - would be that "one would be the only absolutely free person if all the rest lost such privilege completely". This article takes a significantly opposed stance on the issue, and adopts the republican notion of freedom, where this is not understood as absence of interferences, but as absence of arbitrary interferences, i.e., the notion of freedom as non-domination.

Republican freedom tends to be analysed by contrasting it with liberal one. ${ }^{11}$ This is often done by distinguishing between a negative, putatively republican freedom (the right not to be interfered with) and a positive, supposedly liberal one (the right of or to), developed by Isaiah Berlin (1958) on reinterpreting the binary distinction between the "liberty of the ancients" and that of the "moderns", brandished by Benjamin Constant in 1819. Nevertheless, such categorization

$10 \quad$ Aristotle defended the existence of this connection between material dispossession and servitude, according to which the wage labour that was needed due to lack of-property-alternatives was nothing but a "sort of limited slavery" (Pol., 1260a). In 1656, almost two thousand years later, in his famous A Commonwealth of Oceana, James Harrington repeats that: "The man that cannot live upon his own must be a servant; but that can live upon his own may be a freeman" (Harrington, 1992: 269). Two hundred years on, in 1875, a very Aristotelian Karl Marx will insist on this same topic in his Critique of the Gotha Program: "The man who possesses no other property than his labor power must, in all conditions of society and culture, be the slave of other men who have made themselves the owners of the material conditions of labor. He can only work with their permission, hence live only with their permission" (Marx, 1994: 316, emphasis added).

${ }^{11}$ In contrast with the liberal idea of a purely negative freedom, republican freedom is a "dispositional notion" (Domènech, 2000: 30). 
ended up sparking off an academic debate that was utterly disconnected both from the reality of the ancients' and from that of the moderns'. ${ }^{12}$ More recently, the republican type of freedom has been interpreted as a third kind of freedom or a somehow more refined kind of negative liberty: "Being unfree does not consist in being restrained; on the contrary," says Pettit (1997: 5)

the restraint of a fair system of law-a non-arbitrary regime-does not make you unfree. Being unfree consists rather in being subject to arbitrary sway: being subject to the potentially capricious will or the potentially idiosyncratic judgment of another. Freedom involves emancipation from any such subordination, liberation from any such dependency. It requires the capacity to stand eye to eye with your fellow citizens, in a shared awareness that none of you has a power of arbitrary interference over another.

Pettit chooses a definition which is halfway between purely negative freedom and purely positive one in the vein of Berlin. Thus, republican freedom would be a person's (A's) capacity not to be arbitrarily interfered with by one or several other persons. ${ }^{13}$ Consequently, interference of a non-arbitrary kind in A's set of opportunities would be admissible. Antoni Domènech (2000: 30) insisted on this when distinguishing between, on the one hand, domination relationships or arbitrary interferences and, on the other, non-arbitrary ones:

I am free when I am under no one's thumb or authority, when no one-whether he/she actually does it or not-could interfere with my life plans at his or her discretion (...) my liberty is promoted when other free people can interfere with my life in a non-arbitrary way.

Both definitions may prove prolific when it comes to re-thinking the political-normative implications which derive from them. The key point here, though, is to establish which of A's spheres is (or can be) interfered with. In the republican tradition, such sphere is always institutionally marked-notice the methodological assumptions $b$ and $c$ in the republican "social ontology" at the beginning of this writing-and is inextricably linked to the material conditions of both $\mathrm{A}$ and his potential dominators (not only B, but also C, D...). Let us see it this way: an interference of B in the set of A's opportunities which did not affect the conditions for A's autonomous existence (e.g., a white lie) might be ethically or

\footnotetext{
${ }_{12}$ A critique of this binary conception of freedom can be found in Domènech \& Bertomeu (2005), and Holmes \& Sunstein (1999).

${ }_{13}$ Pettit defines the republican freedom with his metaphor of the "eyeball test", which describes that particular social position from which one is able "to look one another in the eyes without reason for fear or deference" (Pettit, 2014: 82).
} 
morally reprehensible but, for republicanism, it would still constitute a political irrelevant (though arbitrary) interference. It would not be the same if B (or C, or D...) is able to make use of A at his own will (as a wage labourer, for instance), as A finds himself institutionally forced to accept this dependent relationship because he lacks the resources or the material conditions that are needed to subsist in an autonomous and independent manner. What is rather politically relevant for republicanism is the fact that which sphere A (and B, and C...) can be interfered with (his array of available opportunities) is something which is always politically and economically regulated.

This is why, once we acknowledge that property (or material independence) is the basis for republican freedom, Berlin's distinction between negative liberty (the freedom from) and positive liberty (the freedom to) loses much of its meaning. Domènech \& Bertomeu (2005: 70) put it this way:

On one hand, it is their freedom to ("positive") govern themselves by administering the material bases for his autonomous existence what trains people in virtue, what ultimately enables them to be free citizens. On the other hand, the state is compelled to intervene "positively" (and, sometimes, at great expense) in the set of opportunities of the myriad of individuals who might try to destroy X's freedom from being interfered with ("negative") in the self-governance of his property ("positive"), as well as it is to "assist" ("positively") $\mathrm{X}$ in his freedom to ("positive") resist the assault in a licit manner.

We shall look into this further below. What we should like to stress now is that (a) Polanyi was always deeply interested in the status of freedom in the industrial society, and (b) his definition of freedom is quite similar to the one we have exposed.14 However, reconstructing his notion of freedom may prove a rather intricate task, since it involves the tracking of countless fragments, chapters, letters, and passages from his journalist articles, opinion notes and books. ${ }^{15}$ However, what is not as difficult to come across is the antagonist of this kind of freedom. For Polanyi, in line with the republican tradition, the opposite of liberty is slavery, i.e., the condition of "being forced or compelled by someone

\footnotetext{
${ }_{14}$ Although Polanyi's theory might be linked with Socialism tradition in the light of several of his assumptions, according to Michael Buroway (2003: 229), one important divergence with this theory might be that he emphasized "a tendency inherent in industrial civilization rather than in capitalism" in itself in talking about social class domination and, thus, the status of freedom in society.
}

${ }^{15}$ This intricate reconstruction of Polanyi's freedom can be found in: Polanyi (1931; GT: 389-408; 1947; 2012: 317-326; and 1959). 
else's will.16" In this sense, Polanyi was a harsh critic of the liberal conception of freedom, since "with the liberal the idea of freedom thus degenerates into a mere advocacy of free enterprise" (GT: 265). ${ }^{17}$

Far from the logic of nineteenth century liberalism, for Polanyi and for republicanism, governments can (and must) interfere in a non-arbitrary manner in the set of opportunities of individuals in order to ensure the material conditions in which freedom can be thought of. ${ }^{18}$ For this, it is essential for the institutional order (basically, the political arrangement of markets and the economy) to recover its "substantive" character and be designed as a means to sustain a certain distribution of wealth, and therefore, of freedom in itself. Consequently, large private powers (brought about by large accumulations of wealth) that are capable of imposing domination relations should not be allowed to exist. So that, "if the property system or distribution has the contingent effect of allowing domination, then that makes a case for institutional adjustment" (Pettit, 2006: 139). Thus, it is possible to understand how Polanyi's concerns always revolved around the material "conditions for freedom." What is really at stake, he declares, is that "the very possibility of freedom is in doubt. It appears that the means of maintaining freedom are themselves adulterating and destroying it;" hence, "the key to the problem of freedom in our age must be sought on this latter plane" (GT: 262).

16 “Jean Jacques Rousseau or ¿it is possible a free society?”, in: Polanyi (2012: 321). Polanyi’s domination relationships (or arbitrary interferences, as republicanism would term them) can be summarized in the (false) "liberty to exploit one's equals, the liberty to obtain exorbitant earnings without providing the community with comparable services, the liberty to prevent technological innovation from being used for public good, or the liberty of benefiting from public calamities by secretly manipulating them for private profit. If such liberty ever disappears, it will be for the good of all” (Polanyi, 1947: 116).

\footnotetext{
${ }^{17}$ Similarly, Erik MacGilvray observes that "From a republican standpoint, the freedom to sell one's labor to the highest bidder is not properly speaking freedom at all, as the various critics of wage slavery never tired of pointing out. From the standpoint of market freedom, by contrast, the effort to preserve or enhance the security of the working class by blocking or regulating voluntary transactions between consenting adults is a manifest and even paradigmatic encroachment on individual liberty" (MacGilvray, 2011: $165)$.

${ }^{18}$ There is a large amount of work arguing about the more or the less radical-interventionist character of Polanyi's framework. Someone interested in should takes into account: Block \& Somers (2014), Dale (2010, 2016), De Castro \& Pereño (2012), Fraser (2012), Halperin (2004), Hodgson (2016), and Mendell (2003).
} 
Emphasizing the need to establish a democratic institutional order that fosters such material conditions, Polanyi (GT: 236) adds that personal freedoms will exist as long as they

deliberately create new safeguards for its maintenance and, indeed, extension. In an established society the right to nonconformity must be institutionally protected. The individual must be free to follow his conscience without fear of the powers.

Freedom, therefore, must be discretionarily protected. Moreover, its protection must achieve its universalization. In this way, the achievement of freedom becomes inextricably linked to the regulation of freedom by producing "spheres of arbitrary freedom protected by unbreakable rules" (GT: 254). Such regulation, nonetheless, must not be understood as some sort of arbitrariness or despotism, neither a loose of freedom, on the part of the political body; it is rather the only way to ensure the material conditions which are needed to universalize freedom. ${ }^{19}$ This is the reason why Polanyi (GT: 262-3) insists that, in the institutional level,

regulation both extends and restricts freedom (...) The comfortable classes enjoy the freedom provided by leisure in security (...) They talk of slavery, while in effect only an extension to the others of the vested freedom they themselves enjoy is intended.

The republican-Polanyian type of freedom demands a "substantive" concept of freedom, or freedom understood as a de iure status which is simultaneously sustained by the material conditions that make it ultimately possible as a de facto reality. Thus, Polanyi's vision is not based on a merely isonomic conception of freedom (or freedom as formal equality in law). Since "no mere declaration of rights can suffice," "institutions are (also) required to make the rights effective." Actually, his contention is that (GT: 264-5):

regulation and control can achieve freedom not only for the few, but for all. Freedom not as an appurtenance of privilege, tainted at the source, but as a prescriptive right extending far beyond the narrow confines of the political sphere into the intimate organization of society itself.

\footnotetext{
${ }^{19}$ In order to develop this point—-something which is beyond the scope of this article—, we should take into account the following explanation: "Thus, implementing the republican ideals does not only demand coping with the imperium - those relations of domination which are derived from the state - but also, and very particularly, with the dominium, i.e., those relations of domination created by dependency bonds rooted in the core of the so-called civil world and which largely give rise to the imperium as well" (Casassas, 2005: 238).
} 
In summary, the normative requirement of the republican-Polanyian kind of freedom demands certain political and legal instruments capable of sustaining it (the required legal-institutional regulation of freedom) but, above all and most importantly, it demands the kind of economic order and material basis that can make it possible. "Hence," Polanyi goes on, the "transcending importance of the institutional aspect of the economy" (Polanyi, 1957: 249). It is not striking that he identified the way in which the market is instituted in society as the prevailing factor in the shaping and ensuring of freedom, since "liberty, in a complex society, demands an inviolable passport. It is necessary to protect the individual against undue pressure, be it by a person or by a company" (Polanyi, 2012: 341). This is how he identifies the sudden emergence of economic liberalism and market society in the nineteenth century as the main historical process by which freedom came to be restricted to the enjoyment of the wealthy classes.

One of Polanyi's major contributions to the study of this period's economy was, no doubt, his description of the processes of communal dispossession or "enclosures of open fields and conversions of arable land to pasture during the earlier Tudor period in England, when fields and commons were hedged by the lords, and whole counties were threatened by depopulation" (GT: 36). His analysis of such processes (termed "primitive accumulation" in the Marx's Capital, ${ }^{20}$ and "accumulation by dispossession" by David Harvey ${ }^{21}$ gained him an insight into the true character of the new mode of production: the fact that the expansion of capitalist-type markets involved an accelerated and virulent destruction of classical freedom based on material independence grounded on the communal and small private property. Such expansion implied a previously unseen increase in the forms of social domination, which were no longer mediated by the feudal bond between a liege lord and a small free tenant, but rather by the formally free contractual relationship between employers and the new industrial proletariat.

\footnotetext{
${ }^{20}$ In the chapter Historical Tendency of Capitalist Accumulation, Marx himself estimates that around 3,511,770 acres of land were taken away or expropriated by large landowners in England between 1810 and 1831. This is what he called the "dissolution of private property based on the labour of its owner" (Marx, 1906, VIII, XXXII).

${ }^{21}$ Harvey (2003: 158).
} 
With this process of dispossession, Polanyi says, the old basic pillars of the whole economy turn to commodities: nature becomes land, fiduciary money becomes an object for speculation, and human beings become labour power. In other words, "the extension of the market mechanism to the elements of industry-labour, land, and money-was the inevitable consequence of the introduction of the factory system in a commercial society." The emergence of such "fictitious commodities2" will cause the collapse of all communities, whose essential institutions will become subsumed under the new logic of commoditization. The most dramatic thing about this is that "the fiction of their being so produced became the organizing principle of society" (GT: 78; 79).

All in all, the process of commoditization of the old forms of popular economy based on common resources represented an unprecedented and traumatic transformation based on the gradual abandonment of all economy in its substantive sense. ${ }^{23}$ When we take this into account, we discover that Polanyi's analysis of such process constitutes one of his major points of connection with the republican tradition, for which freedom is established by and through a basic mainstay: the fact that people cannot be free if their material existence is not politically ensured. And particularly, what links Polanyi with the republicandemocratic tradition is that this must be made extensive to the population as a whole, and not limited to a few. This is the bond between freedom and property in the republican-Polanyian line of thought, which we shall explore in more depth in the following section.

\footnotetext{
${ }^{22}$ In The Economy As Instituted Process (Polanyi, Arensberg, \& Pearson, 1957: 255), Polanyi himself states that "the rise of the market to a ruling force in the economy can be traced by noting the extent to which land and food were mobilized through exchange, and labor was turned into a commodity free to be purchased in the market." Despite the fact that, from a Polanyian perspective, labour is considered as a fictitious commodity, it must be noticed that "it is not even a commodity at all: the relationship established by the owner of labor power when he enters a labor relationship is not a commercial relationship (he is not really selling a specified amount of labor) but a social relationship (he is alienating his labor capacity for a specified time)" (López Calle, 2012: 82).

${ }^{23}$ In this transformation, Polanyi holds, "human society had become an accessory of the economic system. We recall our parallel between the ravages of the enclosures in English history and the social catastrophe that followed the Industrial Revolution. Improvements (...) bought at the price of social dislocation. If the rate of dislocation is too great, the community must succumb in the process" (GT: 79).
} 


\subsection{The Material Conditions for Freedom: Property and Material Independence}

According to Marx, the use of the common resources and small private property in land allowed the bulk of the agrarian population to live "without having to ask for permission." What the process of enclosure meant was the "dissolution of small private property based on personal labour," a condition which had ensured small peasants a certain amount of material independence that, up to a certain extent, made them free from having to sell their labour power in order to subsist. ${ }^{24}$ Clearly, Polanyi subscribed this Marxian logic: the Poor Law Reform of 1834 had led the working poor to beggary. Indigence, massive unemployment, land privatization, and the extinction of the poor laws, mean that the "right to live was abolished" (GT: 86).

As we have already insisted, a republican civil society can only be made up of free individuals, those who are materially autonomous and are not compelled to ask for favours or sell themselves to others. As Aristotle contends (Pol., I, $1317 \mathrm{~b})$, the main "factor of this freedom is to govern and be governed in turn.25" Property as material independence appears once again as the necessary institution by which the popular classes can become part of the civil body as fullright, or sui iuris, citizens (hence the Marxian term "alienation" as an expression of alieni iuris ). David Casassas (2005: 239) puts it this way:

For the bulk of the republican tradition, whether aristocratic or democratic, we can only speak of civil society when there exists an association of individuals who are free and equal-equal meaning equally free-within a community where each and every one of its full-right members enjoys material independence, that is, a guaranteed sphere of autonomous social existence.

The constitution of the civil body, the establishment of republican citizenship, is then founded upon the relationship between freedom and property,

\footnotetext{
${ }^{24}$ Marx might add that "a worker's private property in his own means of production is the foundation of petty industry (this) is an essential condition for the development of social production and of the free individuality of the labourer himself. (...) it flourishes (...) it attains its adequate classical form, only where the labourer is the private owner of his own means of labour set in action by himself: the peasant of the land which he cultivates, the artisan of the tool he handles as a virtuous" (Marx, 1906, VIII, XXXII; emphasis added).

${ }^{25}$ In fact, it was not only Aristotle who contended this, since "almost all the great theorists of citizenship (...) have believed that, in order to be a citizen of a polis, in order to be able to participate fully in public life, one needed to be in a certain socio-economic position (...) People could not act as citizens at all, or could not be expected to act well in the political sphere and to make adequate decisions, unless some attention was paid to matters of their wealth, their well-being and their social and economic status" (King \& Waldron, 1988: 425).
} 
where political-institutional arrangements must always foster and ensure the "autonomous social existence" - or material independence - of the whole group of citizens. According to Birnbaum \& Casassas (2008: 77), "material independence":

constitutes a necessary condition for republican freedom as non-domination, this being understood as the freedom a person enjoys when capable of making choices in all domains of life with the security that nobody will have the possibility to arbitrarily interfere in the decisions she might make with regard to her own life plans.

This is why the republican tradition advocates the creation of an institutional order which would be capable of fulfilling such requirements. According to this, for Polanyi's view the key point here would be not only that self-regulating markets - and, therefore, absolute freedom over one's property - produce desolation in the form of poverty or generalized hunger, but essentially that the final consequence of economic disembeddedness is the inability of the dispossessed to govern themselves and others, i.e., the negation of democracy itself. For this reason, Polanyi advocated the promulgation of those "public interferences" (democratically enacted laws) needed to sustain and extend freedom, since "he who obeys the law he himself sanctioned is free" (Polanyi, 2012: 321).

Surely, speaking of property in the classical world amounts to speaking mostly of (individual or collective) land ownership. However, the modern version of republican material independence is quite different. ${ }^{26}$ However, "the basic idea

\footnotetext{
${ }^{26}$ There are deep differences between classical and modern property. While "the purpose of feudal property seems to has been essentially to organize a territory politically and economically," [in the] "modern property" (...) "the accent has been placed exclusively on the economic organization of production and the facilitation of a system of private exchanges" (Trazegnies, 1978: 78). The pre-modern logical unity of property has been broken in contemporary legislations, through its dissociation into a bundle of rights (use, disposition, organization, withdrawal, alienation, etc.) that all together constitute the essence of the classical idea of property. Present property also refers to the right to dispose freely of one's own (free) labour. Polanyi, like modern republican thought, was aware that the Jeffersonian free-holding citizenship ideal was no longer feasible. In short, the industrial developments "placed the republican association of freedom with economic independence [property] under enormous pressure, and the later 19th century saw a series of efforts to reconcile the ideal of independent proprietorship with the demands of industrial production. The most notable of these was the effort to promote workers' cooperatives as an alternative to wage labour, and thus to replace the hierarchical and authoritarian capitalist factory with a workplace based on principles of individual autonomy and collective self-rule" (MacGilvray, 2011: 164-5). It is by replacing the classical individual ownership of land by a collective and cooperative ownership of the means of production that Polanyi forged his ideal of industrial democracy and cooperative production, which in turn, should be understood as heirs of the republican tradition. In order to follow the historical transition of the republican material independence, see: Domènech (2004a) and Gourevitch (2013)
} 
is still there" suggests Carole Rose (1996: 347), "that property nurtures the independence necessary for political participation,"

\begin{abstract}
but in its modem permutation, this idea becomes a platform for distributive rights. The modern form of the independence argument is that all people should have a voice in the political order, but to acquire that voice they need a secure baseline of property -and if necessary, this baseline must be secured by redistribution. (...) baseline entitlements are just as apt to be described as the right to employment, health care, shelter, or the right to such human capital as education.
\end{abstract}

As Rose points out, to ensure a certain amount of protection vis-à-vis arbitrary interference in the market society is also part of the duty of the so-called welfare state regimes. In effect, the labour legislations of a protective and universalizing kind implemented and constitutionalized from 1945 on (including the rights to strike, to organize trade unions, to collective bargaining, to unemployment and redundancy compensations, to retirement pensions, etc.) may well be understood as a further exponent of the legal codification of the principles of republicanism, principles which were in turn inherited by the mid twentieth century socialist and trade union movements. ${ }^{27}$ The right to "free labour", William H. Simon contends, is a "set of basic and uncontroversial rights associated with (republican) citizenship (...) These rights are reflected in the thirteenth amendment prohibition of 'involuntary servitude,' the statutory criminalization of 'peonage,' and the common law's refusal to specifically enforce ‘personal service’ contracts” (Simon, 1991: 1335).

In short, wage labour contracts are a legal - and above all political institution by which workers are partially protected from possible despotic behaviours by their employers, i.e., workers are collectively provided with a set of political, labour and economic rights which prevent them from being arbitrarily interfered with by their employers. In its modern version, "freedom as nondomination" has been updated in the form of politically and institutionally protected fundamental rights such as the right to free labour subject to political

\footnotetext{
${ }^{27}$ Antoni Domènech expresses this same idea — that of the "political bridling" generated by the political pressures that socialism of republican-democratic tradition exercised upon the despotic relations characterizing the economic-labour sphere - in a more suitable manner when he argues that "the core contribution of the socialist labour movement to contemporary republican democracy (has been) the bottom-up control - however imperfect it be - of the potentially despotic power of large private corporative empires" (Domènech, 2004b: 7). Certainly, Polanyi was pretty aware that "the replacement of private property with socialist relations of production" is a process that "requires first the destruction of the capitalist state and then the creation of a new form of state" (...) "then the passage to socialism cannot be automatic. It can only be the result of a deliberate, collective effort" (Buroway, 2003: 2010).
} 
regulation. ${ }^{28}$ Polanyi acknowledges the particularity of post-war Europe when he adapts the normative codification of classic republicanism to the new context and highlights the importance of labour regulations. Thus, he argues that

His indefeasible rights must be enforceable under the law even against the supreme powers, whether they be personal or anonymous. (...) No mere declaration of rights can suffice: institutions are required to make the rights effective. (...) They must be made to prevail against all authorities (...) The list should be headed by the right of the individual to a job under approved conditions (...) This implies guarantees against victimization however subtle it be. ${ }^{29}$

The idea of the need for "institutional protection" of fundamental rights (above all, the right to non-domination) is a concern already expressed in classic republicanism. In the ancient world, the basic issue revolved around the ways of gaining access to property and thus obtaining the condition of citizenship. In market society, though, "citizenship rights are not determined by one's socioeconomic position - and, in this sense, capitalism can coexist with formal democracy -," while "civil equality does not directly affect class inequality, and formal democracy leaves class exploitation essentially intact” (Wood, 1995: 201). For this reason, it is in the economic sphere where institutions, laws and political safeguards have to be erected in order to enhance the material independence of citizens and, therefore, minimize the domination relationships which are inherent to market society.

For Polanyi, the ultimate point about the "industrial society" is not the abolition of markets, but their regulation and adaptation to the real needs of the populations. What he proposes is to conduct and to embed economic activity and institutions in order to articulate a "substantive economy" (Polanyi, 2009: 75-97) which enhances the material existence of individuals and of society as a whole. And it is precisely this notion of "substantive economy" that most strongly connects his work to republicanism, since, on the contrary, a "formal" conception of the economy "suffocates all possibility of thinking politically about the relationship between the economic and the social spheres," when, actually, "the

\footnotetext{
${ }^{28}$ For an examination of the right to "free labor" and its constitutionalization as a legacy of the republican legal code, as well as of the broader legacy of republican property rights, see Rose (2003, 1996); Sunstein (1993); Michelman (1987); Simon (1991), and Gourevitch (2013).

29 Polanyi (GT: 264; emphasis added).
} 
market economy (...) is always a political-economic system (...) a way of organizing the production of goods which demands a social and political organization to suit its structure and its operation" (Prieto, 1996: 23-24). Both for Polanyi and for republicanism, unveiling the political dimension of the economy becomes central in order to construct and give shape to their political-normative project.

\section{A Republican Reading of Polanyi's Work: Economic Disembeddedness, Countermovement and Political Economy}

In the previous sections, we have limited ourselves to pointing out how Polanyi's work is similar to much of the republican line of thought. Such similarity can be inferred from an analysis of, on the one hand, their use of a very similar social ontology and the adoption of an analogous methodological stance, and on the other hand, their equally similar definitions of the concepts of freedom (as non-domination) and property (as a necessary condition for the institution of freedom, i.e., for the prevention of domination relationships). Next, we shall provide a reading in republican-democratic terms of his two greatest contributions: the concept of economic embeddedness and that of countermovement.

One of Polanyi's major contributions to political thought is his notion of “economic embeddedness" (Granovetter, 1985).30 As we have seen, in archaic societies, land, labour power and money, taken as constitutive elements of economic systems, were subordinated to the logic and operation of other social institutions such as the family, the community or the political institutions (Polanyi, 1957). "Economic disembeddedness," on the contrary, is the phenomenon by which economic activity became dissociated - disembedded from these same institutions. The emergence of self-regulated markets required

\footnotetext{
30 Authors like Geoffrey Hodgson, have pointed out that the Polanyian conception of embeddedness might be contradictory. "Even sympathizers have noted some of the conceptual and analytical problems in Polanyi's work. Among others, Gareth Dale (2010: 246) wrote that his argument concerning 'how economies are embedded in societies (...) lacks precision'. Fred Block and Margaret Somers (2014: 91, 94) noted the 'inconsistencies' and the 'ambiguities in his discussion of embeddedness' in The Great Transformation" (Hodgson, 2016: 14).
} 
nothing less than "the division of society into an economic and a political sphere" and, in effect, "rejected political action on that account." The consequence of it all implied "the recognition of the principle of gain and profit as the organizing force in society" (GT: 178) and, with this, the increasing commoditization of both productive and reproductive social activity. In fact, this self-regulated or pure free market is a utopia, since "free-markets could never have come into being merely by allowing things to take their course" (GT: 145).31

According to Carlos de Castro \& Andrés Pedreño (2012: 11), the process of "disembedding" responds to two closely related factors: on the one hand, a process of "institutional separation" and, on the other, one of "subordination" of one institution to the other. While economic disembeddedness involved the adoption of differential operational and regulative logics by, on one side, the political institution - the state - and, on the other, the economic institution the markets -, this same separation led to the subsumption of the former under the mercantile logic of the latter. In other words, "such an institutional pattern [self-regulated market] could not have functioned unless society was somehow subordinated to its requirements" as, he added, "a market economy can exist only in a market society" (GT: 74). The commoditization processes fostered by this disembedding are also de-democratization processes by which the political sphere becomes disembedded from and subordinated to the economic activity. That is why commoditization presupposes the de-democratization, not only of the economic life, but more especially of the political-civil life.

Simultaneously, and as a reaction to this commoditization process, heterogeneous and contradictory movements operating with an opposite logic emerged. This is the famous Polanyian "counter" or "double movement." As he put it (GT: 136),

the dynamics of modern society has been governed by a double movement: the market expanded continuously but this movement was met by a countermovement checking the expansion in definite directions. Vital though such a countermovement

\footnotetext{
${ }_{31}$ In fact, "no serious defender of market mechanisms (...) would defend [absolute] laissez-faire markets, however, but would most likely endorse market mechanisms as complemented and assisted by whatever political institutions are necessary to ensure that they work well." (Furendal, 2017: 7). It was such a double discourse that Polanyi precisely criticized: "to the politician and administrator laissez-faire was simply a principle of the ensurance of law and order, at minimum cost. Let the market be given charge of the poor, and things will look after themselves" (GT: 135)
} 
was for the protection of society, in the last analysis it was incompatible with the selfregulation of the market, and thus with the market system itself.

It is important to add a few considerations to this. The movement of social defence or "countermovement" constituted an effort to re-embed the economic sphere into the social domain. It was not only an attempt to re-unite both spheres, but to subordinate the economic realm to the political one. Historically, however, it would be a mistake to think that all this countermovement was aimed at redemocratizing the economic and the political lives. $3^{2}$

And again, it is important to notice the similarity between Polanyi's understanding and that of democratic republicanism in this point. The process of disembedding involved the dissolution of small private property based on personal labour due to the enclosure and expropriation of natural resources used for common exploitation. This was followed by the extinction of the ways of life, the sociability patterns, the bonds and the communitarian forms of organization that sustained the so-called "moral economy of the English crowd" (Thompson, 1971, 1991) and the French "popular political economy" (Gauthier, 1992, 2015).33

\footnotetext{
${ }^{32}$ It is rather frequent to mistake this double movement in Polanyi's theory for progressive movements of emancipation, or even for class struggle in Marxian terms. A good illustration of this is Nancy Fraser's (2012) critique of the "double movement" for including practices of exclusion or subjugation of category groups such as women. Historian Sandra Halperin also criticizes the idea of a double movement as an essentially cultural phenomenon, which would not recognize "the existence of exploiters and producers and their differential capacities, limitations, and potentialities, (Polanyi's double movement) is conceived and elaborated largely without references to specific social relations or interest" (Halperin, 2004: 13). If Polanyi's theory of double movement is useful, it is because it contributes to our understanding of the essentially contradictory dynamics arising around the middle of the nineteenth century and triggered by the colonization of the social mechanisms by the practices of the market system. Class struggle, then, cannot be likened to double movement; rather, it should be understood as an integral part-together with other sociohistorical dynamics and phenomena- of the logic of double movement.

33 The political economy of the crowd, as well as the popular political economy, were "grounded upon a consistent traditional view of social norms and obligations, of the proper economic functions of several parties within the community, which, taken together, can be said to constitute the moral economy of the poor" (Thompson, 1991: 188-9). The expression "popular political economy" and its opposite, the "tyrannical political economy", were both originally coined by J. J. Rousseau in his article Political Economy, in volume V of Diderot's and d'Alambert's Enciclopédie of 1755, where he stated: "It would therefore be appropriate to add a further distinction, between the popular and the tyrannical forms of public economy. The first kind is that of every state in which a unity of will and interest reigns between the people and its chiefs; and the second kind necessarily exists everywhere where the government and the people have different interests, and contrary wills as a result" (Rousseau, 1999: 9). Later on, this dichotomistic opposition would be employed by Maximilien Robespierre in his Discours Sur la Constitution May 10, 1793, in Robespierre (1910-67, IX: 508).
} 
Indeed, "the embeddedness position is associated with (...) the idea of "moral economy' in history and political science” (Granovetter, 1985: 482).34

Both expressions of this political economy, in turn, exhibited a strong philosophical substratum coming from the tradition of natural law, 35 including writers such as Bartolomé de las Casas and Francisco de Vitoria, Locke, Paine, Kant, Robespierre or Jefferson, among others. What we should like to highlight here is that the central element around which this natural law tradition revolves is the defence of the right to existence as the guiding principle for both the civil and the economic life. In short, the natural right to existence is given precedence over the civil right to property, which can only be justified as a means to guarantee the former. Two of the main exponents of this natural law trend within modern republicanism were Maximilien Robespierre and Thomas Jefferson. In 1792, the French explicitly incorporated natural law to his political program to defend that the most important of all imprescriptible rights is the right to existence:

The first social law is therefore the one that guarantees to all the members of the society the means to exist. All others are subordinate to this. The property has not been instituted nor guaranteed for anything else than to cement it. They have properties, first, to live. It is not true that property can ever oppose to the subsistence of men. The foods necessary for man are as sacred as life itself. 36

Three years later, Jefferson expressed the same natural law base, although he adopted a certainly different ideological stance:

Whenever there is in any country, uncultivated lands and unemployed poor, it is clear that the laws of property have been so far extended as to violate natural right. The earth is given as a common stock for man to labour \& live on. 37

As we can see, the main concern of both authors is the violation of natural law (first and foremost, of the right to existence). For the Jacobin, the unlimited freedom of commerce and the idea of property as a "sacred right" that were consecrated in the protoliberal Constitution of 1791 constituted an affront to

\footnotetext{
${ }^{34}$ Other authors, like Jeremy Adelman, also assign to the Hungarian a framework considered as "moral economy". Nevertheless, Adelman considers that his "moral economics did as much to obscure the nature of global interdependence as it did to reveal the perils of leaving the invisible hand to its own devices" (Adelman, 2017).

${ }^{35}$ About this natural law substratum, see Bosc (2009, 2011); Gauthier (1992, 2015); and Gauthier \& Ikni (1988). For a sound historical reconstruction of the role of natural law in political thought, see Tierney (1982).

${ }^{36}$ Discours Sur les Subsistances, December 2, 1792, in Robespierre (1910-67, IX: 112-3).

${ }^{37}$ Letter to Reverend James Madison, October 28, 1795, in Jefferson (1904-5, VIII: 196).
} 
natural law (Bosc, 2013: 92-114). For the Virginian, who brandished the flag of the yeomanry, with their freedom and their self-sufficiency based on land ownership, the growing industry, the "moneyed interest" and the corruption of the "pseudo-aristoi" from the North perverted both the virtue and the selfgovernment of the republican citizenry, undermining their material base of existence in favour of an increasingly plutocratic and oligarchic society, as it had happened in senatorial Rome (Domènech, 2004a: 59-72). This is why both revolutionaries can be ascribed to the same tradition of republican freedom (Richard, 1995: 29; Rosenberg, 1966: 17-26).

Polanyi never referred to the notion of natural law. $3^{8}$ However, this did not prevent him from agreeing with both republican thinkers in his analysis: the enclosures, the gradual commoditization of the economy and of the basic resources (among these, the "fictitious commodities"), and the consequent "disembedding" of economy are irremediably at odds with the very possibility of existence of a democratic system and, ultimately, they threaten to put an end to society itself. Once again, Polanyi does not employ the language of natural law. His point of departure is different here from that of natural law republicans. Still, he gets to the same point of arrival: the new enclosures (Boyle, 2003), the mercantilization of both natural resources (Federici, 2004; Rai \& Eisenberg, 2003) and artificial ones (Epstein, 2001; Orsi, 2002), the liberalization of property rights (Singer, 1996; Simon, 1991), and the consequent economic uncoupling and self-regulated markets, do not only constitute a threat to the "natural right" to existence, but also to the very existence of society. He uses a different language indeed, but with the same meaning.

Freedom was always the normative goal of republicanism - be it of an aristocratic or a democratic kind. And, in order to achieve it, a necessary condition was the establishment of suitable, politically designed markets. This is the basic outline of the so-called republican political economy, or the "political economy of democracy” (Casassas \& De Wispelaere, 2016). As some scholars has

\footnotetext{
38 Among other reasons, because the reactionary-Thermidorian program leveraged by Benthamian utilitarianism had already erased all traces of it, as, for Bentham (1931: I, 7-9), rights are "nonsense" and human rights are "nonsense upon stilts.”
} 
also noted, when understood as an "instituted processes of economic democratization" (Mendell, 2003: 7)39, Polanyi's “countermovement" bears a close resemblance to this republican political economy because of the fact that he proscribes the erosion that self-regulated markets inflict on society and on collective and individual self-government. In particular, the most democratic wing of this "countermovement" as this republican political economy alike, seem to be normatively motivated by the necessity to politically bridle the economic activity and institutions in order to offer a more democratic response to the productive and reproductive needs of contemporary societies. Nevertheless, in general, the republican stance can be seen as an option that falls within the "countermovement" logic, which is to say that the republican political economy can be interpreted as an effort to re-embed the economic activity and institutions (especially the institution of property) in its "social ontology" and, consequently, as an effort to subject these to its own political-philosophical principles, most notably, the principle of safeguarding the freedom of citizens, whether the many or the few.

If we have suggested that Polanyi bears a special connection to the more democratic wing of republicanism, this is not because he believes that the aim of the movement for social self-protection should be limited to that of (re)integrating the economic sphere into society, subordinating it and politicizing it. It is because such re-politicization was aimed at re- democratizing the operation and the logic of markets themselves. As a consequence, Polanyi's yearning for "democratic socialism, 40 " when understood as a possible reformulation of the democratic republican political economy, could be interpreted as a kind of

\footnotetext{
39 Marguerite Mendell defends that "Polanyi's writings on economic democracy, his proposal for a functional democracy (functional socialism), influenced by the guild socialism of G. D. H. Cole, the writings of Robert Owen, and especially those of Otto Bauer and the experience of 'Red Vienna' (1917-34), and his writings on education, contribute towards a conceptualization of contemporary processes of institutionalization, in particular, to what I have called instituted processes of economic democratization".

40 For a more in-depth account of Polanyi's "democratic socialism", see Polanyi (1960); and Dale (2016: 218-87). As Marguerite Mendell states, "Karl Polanyi's writings on economic democracy, his proposal for a functional democracy (functional socialism), influenced by the guild socialism of G. D. H. Cole, the writings of Robert Owen, and especially those of Otto Bauer and the experience of 'Red Vienna' (1917-34), and his writings on education, contribute towards a conceptualization of contemporary processes of institutionalization, in particular, to what I have called instituted processes of economic democratization” (Mendell, 2003 :7).
} 
countermovement, not only to re-embed the economy and subordinate it to the social institutions, but also to re-democratize the working of markets and, by extension, the present market society as a whole.

\section{Concluding Remarks: Freedom and Self-Regulated Markets}

In the same manner as the republican tradition was always concerned about the material conditions of existence in order to implement its ideal of freedom, Polanyi always focused on trying to understand the way that the economy was organized within society, or "its place in society" (Polanyi, Arensberg, \& Pearson, 1957: 239-241; Polanyi-Levitt \& Mendell, 1987), in order to include that same requirement. The key element in Polanyi's vision is his determination of how the economic processes become institutionalized throughout history and how they constrain or promote (the conditions for) freedom. In this respect, he always contended that the institutionalization of the economic processes should be carried out by universalizing (the conditions for) freedom. This should be done by regulating the markets and politically interfering in them in order to avoid the possibility that certain actors (using the power conferred to them by their economic wealth) impose their own criteria upon all economic activity and, ultimately, upon the political activity as well. ${ }^{41}$ While the immediate consequence of such lack of regulation would be a disproportionate accumulation of wealth and the subsequent imposition of arbitrary powers, the most devastating result would be the tragedy of fascism and, with it, the extinction of any kind of freedom:

Nowhere did the liberals in fact succeed in reestablishing free enterprise, which was doomed to fail for intrinsic reasons. (...) Planning, regulation, and control, which they wanted to see banned as dangers to freedom, were then employed by the confessed enemies of freedom to abolish it altogether. Yet the victory of fascism was made practically unavoidable by the liberals' obstruction of any reform involving planning, regulation, or control (GT: 265).

As this forceful passage reveals, Polanyian freedom is not an abstract, epistemic notion. It has an intrinsically institutional character contingent on

\footnotetext{
${ }^{41}$ The main interventions or regulations that Polanyi supported are: laws on industrial activity, laws concerning the organization of trade unions, safety regulations for workers, compensations for accidents, housing regulations, the limitation of market prices, laws concerning the exploitation of intercontinental resources, exchange rates, etc. For a more detailed exposition of his proposals, see Polanyi (1936).
} 
society's socioeconomic development and the evolution of its social forces and conflicts. What both Polanyi and the republican tradition are mainly interested in is "the material conditions for freedom." This is what gives so much relevance to the status of economy in society. And it is only after recognizing such a fact, that Polanyi is ready to point out that the dynamics which characterize the "selfregulated" market system constitute a threat to these same "material conditions for freedom". This is also the reason why he - and republicanism - always supported political-economic schemes aimed at re-embedding the economic sphere in the political sphere and subordinating the former to the latter.

As republicanism always believed, and as Polanyi impassively contended, "self-regulated market" and "freedom" are mutually exclusive terms. The republican, and Polanyian, freedom requires the establishment of non-arbitrary mechanisms of intervention in the set of opportunities of the different actors and social groups. In particular, Polanyi and republicanism alike will contend that freedom requires the existence of democratically sanctioned institutional safeguards to restrict the set of opportunities of individuals if such set of opportunities gives them the power to impose his particular will on society as a whole. Because, indeed, freedom "will only exist to the degree in which we will deliberately create new safeguards for its maintenance and, indeed, extension" (GT: 263).

\section{References}

Ackerman, B. (1993). We, the People, Vol. I, Foundations. Cambridge, Mass: Harvard University Press.

Adelman, J. (2017). Polanyi, the Failed Prophet of Moral Economics. Boston Review, May 30 2017. [Online available: http://bostonreview.net/classinequality/jeremy-adelman-polanyi-failed-prophet-moral-economics, access retrieved: September 12, 2017].

Aristotle (1997). Politics (trans. A. Rackham). London: William Heinemann, Ltd. 
Baum, G. (1996). Karl Polanyi on Ethics and Economics. Montreal: McGillQueen's University Press.

Bentham, J. (1931). The Theory of Legislation: Civil Code. London: Ogden.

Berlin, I. (2009 [1958]). Sobre la libertad (trans. Á. Rivero). Madrid: Alianza Editorial.

Bertomeu, M. J. (2005). Republicanismo y propiedad. El Viejo Topo, 205206, 84-89.

Bertomeu, M. J. (2004). De la apropiación privada a la adquisición común originaria del suelo. Un cambio metodológico 'menor' con consecuencias políticas revolucionarias. Isegoría, 30, 141-147.

Birnbaum, S. \& Casassas, D. (2008). Social Republicanism and Basic Income, in: D. LEIGHTON \& S. WHITE, (eds.). Building a Citizen Society: The Emerging Politics of Republican Democracy. London: Lawrence \& Wishart, 7582.

Block, F. (2003). Karl Polanyi and the Writing of 'The Great Transformation'. Theory \& Society, 32 (3), 275-306.

Block, F. \& Somers, M. (2014). The Power of Market Fundamentalism: Karl Polanyi’s Critique. Cambridge, MA: Harvard University Press.

Bosc, Y. (2013). Robespierre Libéral. Annales historiques de la Révolution française, 1, 95-114.

Bosc, Y. (2011). Liberté et propriété. Sur l'économie politique et le républicanisme de Condorcet. Annales historiques de la Révolution française, 4 , $53-82$.

Bosc, Y. (2009). Le conflit des conceptions de la république et de la liberté : Thomas Paine contre Boissy d'Anglas, in: M. Belissa Y. Bosc, \& F. Gauthier (eds.). Républicanismes et droits naturelsà l'époque moderne. Des humanistes aux révolutions des droits de l’homme et du citoyen. París: Kimé, 101-115.

Boyle, J. (2003). The Second Enclosure Movement and the Construction of the Public Domain. Law and Contemporary Problems, 66, 33-74. 
Burawoy, M. (2003). For a Sociological Marxism: The Complementary Convergence of Antonio Gramsci and Karl Polanyi. Politics \& Society, 31, 193261.

Casassas, D. (2013). Adam Smith's Republican Moment: Lessons for Today's Emancipatory Thought. Economic Thought, 2 (2), 1-19.

Casassas, D. (2011). La ciudad en llamas. La vigencia del republicanismo comercial de Adam Smith. Barcelona: Montesinos.

Casassas, D. (2007). Basic Income and the Republican Ideal: Rethinking Material Independence in Contemporary Societies. Basic Income Studies, 2 (2), $1-7$.

Casassas, D. (2005). Sociologías de la elección y nociones de libertad: la Renta Básica como proyecto republicano para sociedades de Mercado. Isegoría, $33,235-248$.

Casassas, D. \& De Wispelaere, J. (2016). Republicanism and the political economy of democracy. European Journal of Social Theory, 19 (2), 283-300.

Casassas, D. \& Raventós, D. (2007). Propiedad y libertad republicana: La Renta Básica como derecho de existencia para el mundo contemporáneo, Sin Permiso, 2, 35-69.

Dale, G. (2016). Karl Polanyi. A Life on the Left. New York: Columbia University Press.

Dale, G. (2010). Karl Polanyi: The Limits to the Market. Cambridge: Polity Press.

Dagger, R. (2006). Neo-republicanism and the civic economy. Politics, Philosophy \& Economics, 5 (2), 151-173.

De Castro, C. \& Pereño, A. (2012). El péndulo de Polanyi: de la desdemocratización a la resistencia social. AREAS. Revista Internacional de Ciencias Sociales, 31, 8-24. 
Domènech, A. (2005). Entrevista político-filosófica, in: M. J. Bertomeu, A. Domènech, \& A. De Francisco (eds.). Republicanismo y democracia. Buenos Aires: Miño y Dávila, 281-314.

Domènech, A. (2004a). El eclipse de la fraternidad: una revisión republicana de la tradición socialista. Barcelona: Crítica.

Domènech, A. (2004b). Basic Income and the Present Threats to Democracy, Workshop procedure n. 10, Basic Income European Network (September 19-20, 2004), Barcelona. (Available online: www.basicincome.org/bien/pdf/2004Domenech.pdf).

Domènech, A. (2000). Individuo, comunidad y ciudadanía, Contrastes. Revista Interdisciplinar de Filosofía, 5, 27-42.

Domènech, A. \& Bertomeu, M. J. (2005). Algunas observaciones sobre el método y la substancia normativa en el debate republican, in: M. J. Bertomeu, A. Domènech, \& A. De Francisco (eds.). Republicanismo y Democracia. Buenos Aires: Miño y Dávila, 21-40.

Ely, J. W. Jr. (1992 [1938]). The Guardian of Every Other Right: A Constitutional History of Property Rights. Oxford: Oxford University Press.

Epstein, R. A. (2001). Intellectual Property: Old Boundaries and New Frontiers, Indiana Law Journal, 76 (4), 803-827.

Federici, S. (2004). Caliban and the Witch. Women. The Body and Primitive Accumulation. New York: Autonomedia.

Fraser, N. (2012). Can society be commodities all the way down? Polanyian relections on capitalist crisis, Working Paper n.18, Fondation Maison des Sciences de l'Homme, Paris.

Furendal, M. (2017). Defining the duty to contribute: Against the market solution. European Journal of Political Theory, February 20, 2017 [Online available: https://doi.org/10.1177/1474885117693401, access retrieved: September 12, 2017]. 
Gauthier, F. (2015). Political Economy in the Eighteenth Century: Popular or Despotic? The Physiocrats Against the Right to Existence. Economic Thought, 4, 47-66.

Gauthier, F. (1992). Triomphe et mort du droit naturel en Révolution, 17891795-1802. Paris: Press Universitaires de France.

Gauthier, F. \& Ikni, G. R. (comps.). (1988). La Guerre du blé au XVIIIe siècle. La critique populaire contre le libéralisme économique au XVIII siècle. Paris: La Passion.

Goodin, R. E. (2003). Folie Républicaine. Annual Review of Political Science, 6, 55-76.

Gourevitch, A. (2013). Labor Republicanism and the Transformation of Work. Political Theory, 41 (4), 591-617.

Granovetter, M. (1985). Economic Action and Social Structure: The Problem of Embeddedness. The American Journal of Sociology, 91 (3), 481-510.

Halperin, S. (2004). War and Social Change in Modern Europe. The Great transformation Revisited. Cambridge: Cambridge University Press.

Harrington, J. (1992 [1656]). The Commonwealth of Oceana and A System of Politics, J. G. A. Pocock (ed.). New York: Cambridge University Press.

Harvey, D. (2003). The New Imperialism. Oxford: Oxford University Press.

Hodgson, G. (2016). Karl Polanyi on economy and society: a critical analysis of core concepts. Review of Social Economy, 75, (1), 12-40.

Holmes, S. \& Sunstein, C. (1999). The Cost of Rights. Why Liberty depends on taxes. New York \& London: W.W. Norton \& Company.

Jefferson, T. (1904-5). The Works of Thomas Jefferson. XII Vols., P. L. Ford (ed.). New York \& London: The Knickerbocker Press.

King, D. \& Waldron, J. (1988). Citizenship, Social Citizenship and the Defence of Welfare Provision. British Journal of Political Science, 18, 415-443. 
Laín, B. (2014). Karl Polanyi, republicanismo democrático y los fundamentos materiales de la libertad. Encrucijadas, 7, 112-133.

López Calle, P. (2012). La constitución del trabajo como mercancía: el caso español. AREAS. Revista Internacional de Ciencias Sociales, 31, 81-94.

MacGilvray, E. (2011). The Invention of Market Freedom. Cambridge: Cambridge University Press.

Marx, K. (1994 [1875]). Critique of the Gotha Programme. L. H. Simon (ed.). Karl Marx. Selected Writings. Indianapolis \& Cambridge: Hackett Publishing Company, Inc.

Marx, K. (1906). Capital. A Critique of Political Economy. (trans. S. Moore \& E. Aveling). New York: The Modern Library, Random House, Inc.

Meade, J. (1964). Efficiency, Equality, and the Ownership of Property. London: George Allen \& Unwin.

Mendell, M. (2003). Karl Polanyi and Instituted Process of Economic Democratization, Polanyian Perspectives on Instituted Economic Processes, Development and Transformation. Workshop proceeding, Centre for Research on Innovation and Competition, University of Manchester October 23-25, 2003.

Michelman, F. I. (1987). Possession vs. Distribution in the Constitutional Idea of Property. Iowa Law Review, 72, 1319-1350.

Mundó, J. (2015). Political Freedom in Locke’s Republicanism. in: Y. Bosc, R. Dalisson; J. Y. Frétigné, C. Hamel y C. Lounissi (dirs.). Cultures des républicanimses. París: Éditions Kimé, 103-116.

Mundó, J. (2005). Autopropiedad, derechos y libertad (¿đdebería estar permitido que uno pudiera tratarse a sí mismo como a un esclavo?). in: M. J. Bertomeu, A. Domènech, \& A. de Francisco (eds.). Republicanismo y democracia. Buenos Aires: Miño y Dávila Editores, 187-208.

O’Neill, M. \& Williamson, T. (2012). Property-Owning Democracy: Rawls and Beyond. Boston: Wiley-Blackwell. 
Orsi, F. (2002). La constitution d'un droit de propriété intellectuelle sur le vivant aux Etats-Unis: origine et ignification économiques d'un dépassement de frontière. Revue d'Economie Industrielle, 99, 65-86.

Pettit, P. (2014). Just Freedom: A Moral Compass for a Complex World. New York: W. W. Norton \& Company, Inc.

Pettit, P. (2006). Freedom in the Market. Politics, Philosophy \& Economics, 5 (2), 131-149.

Pettit, P. (1997). Republicanism. A theory of Freedom and Government. Oxford: Clarendon Press.

Pocock, J. G. A. (1975). The Machiavellian Moment. Florentine Political Thought and the Atlantic Republican Tradition. Princeton: Princeton University Press.

Polanyi, K. (2012). Karl Polanyi. Textos Escogidos. J. L. Laville, M. Mendell, K. Polanyi Levitt, \& J. L. Coraggio (eds.). Buenos Aires: Clacso.

Polanyi, K. (2009 [1977]). El sustento del hombre. (trans. E. G. Parro). Madrid: Capitán Swing.

Polanyi, K. (1960). Personal Statements, Karl Polanyi Archive, Container 30, Folder 2, Karl Polanyi Institute of Political Economy, Concordia University, Montreal, Canada.

Polanyi, K. (1959). Galbraith's Farewell to Poverty. Karl Polanyi Archive, Container 37, Folder 11, Karl Polanyi Institute of Political Economy, Concordia University, Montreal, Canada.

Polanyi, K. (1957). Aristotle Discovers The Economy, in: K. Polanyi, C. M. Arensberg, \& H. W. Pearson (eds.). Trade and Market in the Early Empires, Economies in History and Theory. Illinois: The Free Press \& The Falcon's Wing Press, 64-94

Polanyi, K. (1947). Our Obsolete Market Mentality. Commentary, 3, 109117 . 
Polanyi, K. (2001 [1944]). The Great Transformation. The Political and Economic of Our Time. Boston, Mass: Beacon Press.

Polanyi, K. (1936). Economic Liberalism vs Interventionism. Karl Polanyi Archive, Container 15, Folder 4, Karl Polanyi Institute of Political Economy, Concordia University, Montreal, Canada.

Polanyi, K. (1934). Marxism Re-Stated. New Britain, July 4, 1934.

Polanyi, K. (1931). The Paradox of Freedom. Conference at Birkbeck College, Container 21, Folder 1, Karl Polanyi Institute of Political Economy, Concordia University, Montreal, Canada.

Polanyi, K.; Arensberg, C. M. \& Pearson, H. W. (eds.). (1957). Trade and Markets in the Early Empires. Illinois: The Free Press \& Falcon's Wing Press.

Polanyi-Levitt, K. \& Mendell, M. (1987). Karl Polanyi: His Life and Times. Studies in Political Economy, 22, 7-39.

Prieto, C. (1996). Karl Polanyi: crítica del mercado, crítica de la economía. Política y Sociedad, 21, 23-34.

Rai, A. K. \& Eisenberg, R. S. (2003). Bayh-Dole Reform and the Progress of Biomedicine. Law and Contemporary Problems, 66 (288), 289-314.

Raventós, D. (2007). Basic Income: The Material Conditions of Freedom. London: Pluto Press.

Rawls, J. (2001). Justice as Fairness : A Restatement. Cambridge, MA: Harvard University Press.

Richard, C. J. (1995). The Founders and the Classics. Greece, Rome, and the American Enlightenment. Cambridge, Mass: Harvard University Press.

Robespierre, M. (1910-67). Oeuvres complètes de Maximilien Robespierre. X Vols., E. Leroux, G. Laurent, M. Bouloiseau, G. Lefebvre, A. Soboul, \& J. Dautry (eds.). Paris: Société des Études Robespierristes, Libraire Félix Alcan, \& Press Universitaires de France. 
Rose, C. M. (2003). Romans, Roads, and Romantic Creators: Traditions of Public Property in the Information Age. Law and Contemporary Problems, 66, 89-110.

Rose, C. M. (1996). Property as the Keystone Right? Notre Dame Law Review, 71 (3), 329-366.

Rosenberg. A. (1966 [1937]). Democracia y socialismo. Aporte a la historia política de los últimos 150 años. Buenos Aires: Editorial Claridad.

Rousseau, J. J. (1999). The Social Contract. (trans. by Christopher Betts). Oxford: Oxford University Press.

Simon, W. H. (1991). Social-Republican Property. University of California Law Review, 38, 1335-1415.

Singer, J. W. (1996). No Right to Exclude: Public Accommodations and Private Property. Northwestern University Law Review, 90 (4), 1283-1499.

Skinner, Q. (2008). Hobbes and Republican Liberty. Cambridge: Cambridge University Press.

Skinner, Q. (1998). Liberty before Liberalism. Cambridge: Cambridge University Press.

Sunstein, C. R. (2004). The Second Bill of Rights: FDR's Unfinished Revolution, and Why We Need It More than Ever. New York: Basic Books.

Sunstein, C. R. (1993). On Property and Constitutionalism. Cardozo Law Review, 14, 907-35.

Trazegnies, G, F. (1978): La transformación del derecho de propiedad. Derecho PUCP, 33, 75-104.

Thompson, E. P. (1991). Customs in Common. London: Penguin Books.

Thompson, E. P. (1971). The Moral Economy of the English Crowd in the Eighteenth Century. Past \& Present, 50, 76-136.

Tierney, B. (1982). Religion, Law, and the Growth of Constitutional Thought. 1150-1650. Cambridge: Cambridge University Press. 
White, S. (2011). The Republican Critic of Liberalism. Critical Review of International Social and Political Philosophy, 14 (5), 561-579.

Wood, E. M. (2008). Why it Matters. London Review of Books, 30 (18), 36.

Wood, E. M. (1995). Democracy Against Capitalism. Cambridge, UK: Cambridge University Press.

Zaman, A. (2016). The Methodology of Polanyi's Great Transformation. Economic Thought, 5 (1), 44-63. 